\title{
FACTORS AFFECTING THE QUALITY OF PROFIT IN INDONESIA BANKING COMPANIES
}

\author{
Ardik Rahmat Kurniawan* \\ Muhammad Khafid \\ Universitas Negeri Semarang
}

\begin{abstract}
The aim of this research is to prove empirically the influence of Managerial Ownership, institutional ownership, profit growth, liquidity, and firm size on profit quality. Data that used to this research is secondary data and that data are taken from the official website of Indonesia Stock Exchange. The populations of this research are all of Banking Companies that list on Indonesia Stock Exchange (BEI) year 2012-2014 that numbered 42 companies. The samples that used to this research are 48 unit of analysis, with method of choosing the samples is purposive sampling technique. The analysis method used for this research is multiple linear regression analysis that analyzed with SPSS 21 program. The result shows that variable of institutional ownership and firm size influence on profit quality. Whereas managerial ownership, profit growth and liquidity does not affect to profit quality.
\end{abstract}

Keywords: Ownership; Profit Growth; Liquidity; Firm Size; Profit Quality

\section{INTRODUCTION}

Financial statement is a communication medium that is used to connect the related parties to a company. Financial statement becomes a main tool for companies to submit financial information regarding the accountability of the management (Schipper \& Vincent, 2003). Submission of information through the financial statements needs to be done to meet the needs of external and internal parties who have authority to obtain the information they need directly from the company's source. Importance of profits information for the users makes each company competing to increase its profits. However, there are certain parties who do unfair way to achieve individual goals to the information of corporate profits. This is what makes the practice of profits manipulation at the time is also frequently done by the management of the company that knows the conditions in the company. It intends to attract investors to invest their funds in the companies.

Some cases of profits management that occurred in Indonesia indirectly indicate poor profits quality reported. For example, a case of profits management that occurred in Lippo bank, it has been occurred differences of financial statement of Lippo bank per September 30, 2002, between which was published in the media and that reported to Jakarta Stock Exchange (JSE). In a report that was published by the print media on $28^{\text {th }}$ November 2002 mentioned that total assets of the company in the amount of Rp 24 trillion with a net profit of Rp 98 trillion. Whereas, in a report of JSE on $27 \mathrm{t}^{\mathrm{h}}$ December 2002, total assets decreased to Rp 22.8 trillion and net loss (unaudited) became Rp 1.3 trillion. 
This phenomenon indicates the occurrence of financial scandals is the failure of financial statements to meet the information needs of report users. Profit as a part of the financial statements does not present actual facts about the economic condition of the company so that the profits that are expected able to provide information to support decision making becomes questionable quality. Profit that does not show actual information about management performance can mislead the parties of report users. If the profit is used by investors to establish the market value of the company, then profit cannot explain the company's actual market value. Profits quality in particular and the quality of financial statement in general are important for those who use financial statements due to contract objectives and investment decision making (Schipper \& Vincent, 2003). For investors, profit report is considered having the information to analyze the shares issued by the issuer.

Earnings Management conducted by the management in the process of preparing the financial statements in order to influence the rate of profit shown which is expected to enhance firm value at the certain moment. Performance engineering known as earnings management is in line with agency theory that emphasizes the importance of the owner of the company (principles) hand over management of the company to the professionals (agents) who more know and understand how to run a business.

Some previous researchers have elaborated several factors that affect the quality of profits, namely Irawati (2012), Yushita \& Triatmoko (2013), Dira \& Astika (2014), Moradi \& Nezami (2011) and Mojtahedi (2013). The results of the study showed that capital structure, profit growth, firm size, liquidity, independent commissioners, the structure of the board of directors, the quality of external auditor, managerial ownership, institutional ownership, audit committee, intellectual capital and debt to equity ratio influence profits management. Based on the previous research, it is still found several variables that show different results. Moradi \& Nezami (2011) produced findings that institutional ownership does not have effect on earnings management, otherwise Irawati (2012) found that institutional ownership affects earnings management. As well as institutional ownership, institutional ownership variable, profit growth, liquidity and firm size have different findings when used in describing the factors that have an influence on earnings management. Because of these various findings, it is necessary to conduct re-research. This study is an amalgamation of several previously research that have different research results about the factors that affect the quality of earnings.

In agency theory, according to Jansen and Mackling (1976), high managerial ownership can reduce the conflict between principal and agent. The existence of managerial stock ownership in a company will encourage the pooling of interest between agents and principals so that managers will act in accordance with the expectation of the shareholders. managers will try to reduce their opportunistic actions to pursue common interests with shareholders. Ross et al in Siallagan \& Machfoedz (2006) states that the greater the management ownership in the company, the management will be inclined to strive improving its performance for the benefit of shareholders and for its own interests. The greater the proportion of managerial stock ownership in the company so that the management tend to try harder for the benefit of the shareholders that no other is itself. Management stock ownership will help the unification of managers 
and shareholders' interests so that managers to feel directly the benefits of the decisions taken and also to bear the loss as a consequence of making a wrong decision.

H1: Managerial Ownership Influences to the Quality of Profit

Institutional ownership is company shares ownership by financial institutions such as insurance companies, banks, pension funds, and investment banking. Certain percentage of shares that is owned by institutions can influence the process of preparing financial statements that does not rule out the possibility there is an actualization in accordance with the interests of the management (Veronica and Sidharta, 2005). Institutional ownership has an ability to control the management through monitoring process effectively thereby reducing management action to do earnings management. Research conducted by Hashim \& Devi (2008) in Yushita \& Triatmoko (2013) found that institutional ownership positively affects the quality of profits. The bigger the role of corporate governance in the company, then the role of institutional investors will be very important. This is related to the role of institutional investors in monitoring the performance of the company, to prevent conflicts of interest from minority shareholders of the company. The greater institutional ownership, then the role of institutional ownership will be greater in the mechanism of corporate governance so that aspects of monitoring on the performance of the company will increase. High profits quality will pressure management to improve its performance, reduce earnings management actions and generate qualified profits reports.

H2: Institutional Ownership Influences to the Quality of Profit

Profit growth is a profit rise or profit decline per year that is stated in percentages (Irmayanti in Irawati 2012). Profit growth is possible to have influence to the quality of company's profit as if a company that has a chance to grow on its profit means that financial performance of that company well and it is also possible to have a chance to grow on the profit quality. The profit growth may affect profit quality. It is in accordance with previous findings which show that profit growth negatively affects to profits quality Irawati (2012). Profit of a company from year to year may increase or experience decrease. Profit rise that is stable from a company shows good corporate profit growth. Vice versa, profit decline from year to year shows that corporate profit growth is less good. If the greater the profit growth, then the higher the chance of companies to gain or increase profits that is obtained by the company in the future. Profit growth is one of the factors that affect the company's profit. It is due to companies with a high level of profit growth considered will produce high profits as well in the future. This indicates that the company does not need to manipulate profits to improve the quality of profits.

H3: Profit Growth Influences on the Quality of Profits

According to Wulansari (2013), the level of liquidity reflects companies' ability to meet short-term obligations just in time. For some companies, the right level of liquidity needs to be maintained. It is due to the level of liquidity related to its interests with the creditors, it also affects to the firm's value in the eyes of investor. The research conducted by Irawati (2012) also states that liquidity negatively significantly influences on the quality of profits. However, the research conducted by Wulansari (2013), states that liquidity positively significantly influences on the quality of profits. According to Siamat in Hesti \& Syaichu 
(2010), a bank is considered liquid if having number of liquidity equal to the number of its liquidity needs, having liquidity less than needs but having bank securities which can be readily converted into cash, and having ability to obtain liquidity by creating debt. While, according to Kusumo in Hesti \& Syaichu (2010) a bank is stated liquid if the bank is able to meet their debt obligations, able to pay back all deposits of the customers, able to meet financing request submitted without going suspension. Company with high liquidity will have a relatively small risk so that creditors feel sure in giving loans to companies and investors will be interested to invest their funds into the company because the investors are sure that the company can survive.

H4: Liquidity Influences to the Quality of Profits

Firm size is a scale in which a company can be classified into small or big companies according to a variety of ways, including total assets, log size, sales and stock market value. Research conducted by Diantimala (2008), states that firm size significantly affects positive. Companies that go public typically tend to have large firm size. Magnitude of size of a company will be more supervised by concerned parties, especially by investors, investors will usually more interested in a large company, because it will make company become more stable and able to generate bigger profit compared with smaller companies.

H5: Firm size Influences to the Quality of Profit

Based on the explanation above, the theoretical framework of this study can be illustrated in Figure 1.

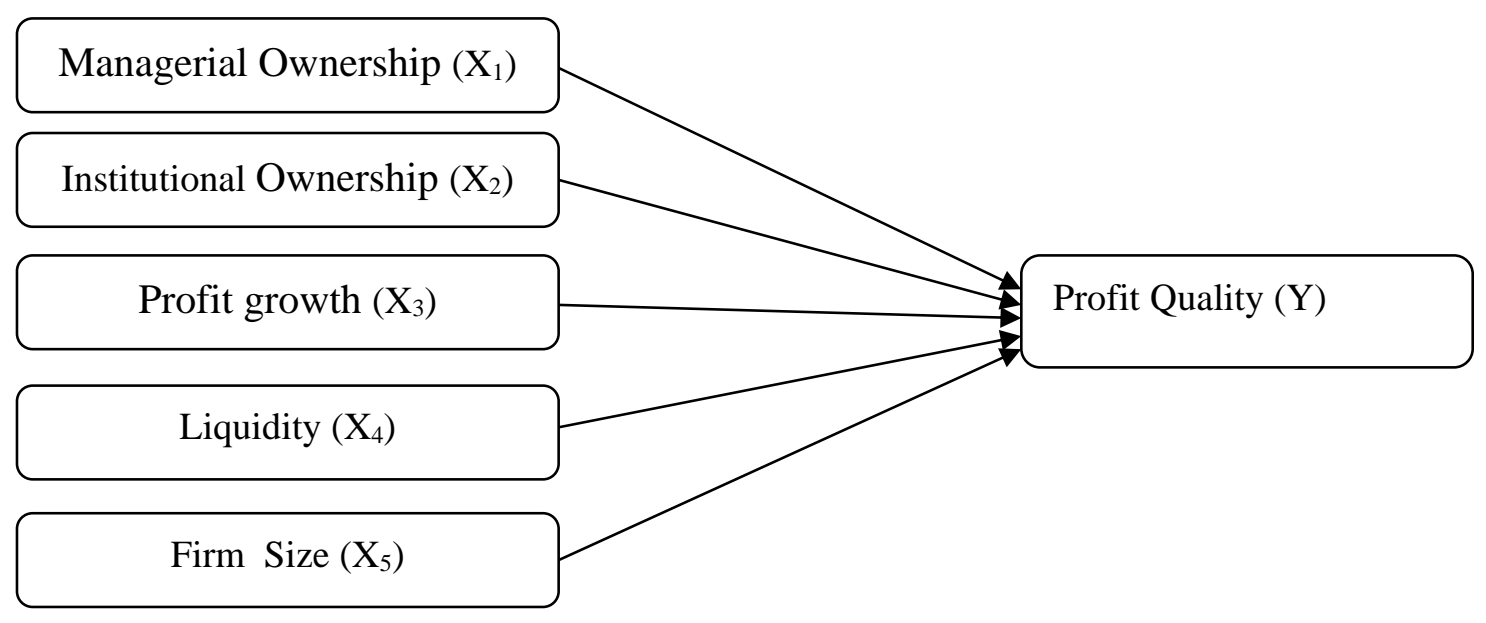

Figure 1

Theoretical Framework 


\section{METHODS}

The population in this study was all banking companies listed in Indonesia Stock Exchange (BEI) in the year 2012 to 2014, amounting to 42 companies. In this study, samples were taken by using purposive sampling method. Purposive sampling method limits the sample to be studied based on certain criteria.

Table 1. Criteria of Sampling

\begin{tabular}{|c|c|c|}
\hline No. & Identification of Company & $\begin{array}{l}\text { Number of } \\
\text { Company }\end{array}$ \\
\hline 1 & $\begin{array}{l}\text { Banking companies listed on the Indonesia Stock Exchange in the period 2012- } \\
2014\end{array}$ & 42 \\
\hline 2 & Companies that did not publish annual report in the period 2012-2014. & $(12)$ \\
\hline 3 & Companies that suffered loss & $(7)$ \\
\hline \multirow[t]{5}{*}{4} & $\begin{array}{l}\text { Companies that do not meet the criteria associated with the variables used in the } \\
\text { study. }\end{array}$ & $(6)$ \\
\hline & The number of samples companies used & 17 \\
\hline & The number of research year & 3 \\
\hline & Samples of the research $(17 \times 3)$ & 51 \\
\hline & Outlier Data & (3) \\
\hline
\end{tabular}

Source :Secondary data processed, 2016

The variables used in this study consisted of dependent variablesand independent variables. Dependent variable in this research was Quality of Earnings. While the independent variables in this research were managerial ownership, institutional ownership, profit growth, liquidity and size of the company.

Table 2. Definition of Research Variable Operational

\begin{tabular}{|c|c|c|c|}
\hline No & Variables & Explanation & Measurement \\
\hline 1 & $\begin{array}{l}\text { Quality of } \\
\text { Earnings }\end{array}$ & $\begin{array}{l}\text { The quality of earnings is the } \\
\text { accounting profit that has little or } \\
\text { notcontaining perceived noise, and } \\
\text { may reflect the company's actual } \\
\text { financial performance. }\end{array}$ & $\begin{array}{l}\text { Standard deviation of net profit during } 5 \\
\text { years }\end{array}$ \\
\hline 2 & $\begin{array}{l}\text { Managerial } \\
\text { Ownership }\end{array}$ & $\begin{array}{l}\text { Managerial ownership is a share } \\
\text { ownership owned by the company } \\
\text { management, as measured by the } \\
\text { percentage of shares owned by } \\
\text { management. }\end{array}$ & $\begin{array}{l}\text { Managerial } \quad \text { Ownership }= \\
\frac{\text { Number of shares owned by managerial }}{\text { Number of outstanding shares }} \times 100 \%\end{array}$ \\
\hline
\end{tabular}




\begin{tabular}{|c|c|c|c|}
\hline No & Variables & Explanation & Measurement \\
\hline 3 & $\begin{array}{l}\text { Institutional } \\
\text { Ownership }\end{array}$ & $\begin{array}{l}\text { Institutional ownership is a share } \\
\text { ownership owned by the government, } \\
\text { financial institutions, institutional } \\
\text { legal entities, foreign institutions, } \\
\text { trust funds and other institutions at } \\
\text { the end of the year. }\end{array}$ & $\begin{array}{l}\text { Institutional } \quad \text { Ownership } \\
\frac{\text { Number of shares owned by institution }}{\text { Number of outstanding shares }} \times 100 \%\end{array}$ \\
\hline 4 & $\begin{array}{l}\text { Profit } \\
\text { Growth }\end{array}$ & $\begin{array}{l}\text { Profit growth is an increase in profit } \\
\text { rise or profit decline per year that is } \\
\text { stated in percentages. }\end{array}$ & $\begin{array}{l}\text { Growth } \quad \text { Profit } \\
\frac{\text { net profit year } \mathrm{t}-\text { net profit year } \mathrm{t}-1}{\text { net profit year } \mathrm{t}-1} \times 100 \%\end{array}$ \\
\hline 5 & Liquidity & $\begin{array}{l}\text { Liquidity ratio is a ratio that indicates } \\
\text { the ability of a company to meet its } \\
\text { financial obligation that must be } \\
\text { fulfilled or the company's ability to } \\
\text { meet financial obligation at the time } \\
\text { billed. }\end{array}$ & Current Ratio $=\frac{\text { CurrentAssets }}{\text { CurrentLiabilities }}$ \\
\hline 6 & Firm size & $\begin{array}{l}\text { Firm size is a scale in which a } \\
\text { company can be classified into small } \\
\text { or big companies according to a } \\
\text { variety of ways, including total assets, } \\
\text { log size, sales and stock market value. }\end{array}$ & Size $=$ Log of Total Asset \\
\hline
\end{tabular}

\section{RESULTS AND DISCUSSION}

Hypothesis testing was done by using multiple regression analysis. Multiple regression analysis made it easy for the researchers to enter more than one predictor variable. This testing was conducted to determine the effect of the independent variable on the dependent variable.

Table 3. The Result of Hypothesis Test

\begin{tabular}{llll}
\hline Model & B & Std. Error & Sig. \\
\hline (Constant) & -15240475608847.557 & 3859560416998.551 & .000 \\
MANOWN & -32337999834.977 & 29130795943.881 & .273 \\
INSOWN & -16636104996.602 & 7205587573.097 & .026 \\
GROWTH & 9475502909.929 & 5986277906.723 & .121 \\
CR & -194801539922.345 & 823908675741.805 & .814 \\
SIZE & 1232403330824.929 & 248870848336.833 & .000 \\
\hline
\end{tabular}

Managerial ownership was a situation where the manager has shares of the company. In other words, the manager acts as the agent and the principal party at the same time. From the analysis result about the 
effect of managerial ownership on the quality of earnings, it could be seen in table 3 which showed the significant value above 0.05 was equal to 0.273 , which meant $\mathrm{H} 1$ in this study was rejected. It could be interpreted that managerial ownership did not affect to the profit quality of a company. This study supported the result of research conducted by Yushita \& Triatmoko (2013) in which the results showed not significant effect between managerial ownership on the quality of profits. However, the result of this study was not in accordance with the hypothesis formulated and did not support finding by Siallagan \& Machfoedz (2006) in which the result of study showed a significant effect between managerial ownership on the quality of profits. Managerial ownership did not influence on the quality of profits was presumably because the manager was not motivated by individuals goals such as earnings management but more aimed at their main result objectives for the benefit of the organization.

Institutional ownership is a proportion of the company's shares ownership by institutions. The definition of an institution that is private companies, securities companies, investment companies, banks, NGOs and other institutions such as pension funds. The analysis result about the influence of institutional ownership on the quality of profits could be seen in table 3 that showed a significance value $<0.05$ that was 0.026 , which meant $\mathrm{H} 2$ in this study was accepted. It could be interpreted that institutional ownership affected to the profit quality of a company. The result of this study supported the research conducted by Hashim and Devi in Yushita \& Triatmoko (2013) which stated that high institutional ownership will pressure management to improve its performance, reduce earnings management actions and generate qualified profit reports. This finding showed that institutional ownership is one of the corporate governance mechanisms that is capable of affecting the quality of profits. In its relation with a monitor function, institutional investors were believed to have ability to monitor management actions better than individual investor. Institutional ownership had ability to control the management through monitoring process effectively thereby reducing management actions to do earnings management.

Profit growth was a profit rise or profit decline per year that was stated in the percentages. Profit growth could be measured by net income earned in year $t$ minus net income earned in year $t-1$ divided by net income earned in year t-1. Profit growth indicated profit rise that occurred during certain period. From analysis results about the effect of profit growth on the quality of profits, could be seen in table 3 that showed significant value $>0.05$ that was 0.121 meant $\mathrm{H} 3$ in this study was rejected. It could be interpreted that profit growth did not affect to profit quality of a company. This research was in accordance with research conducted by Dira \& Astika (2014) which stated that profit growth did not affect to profit quality. However, the result of this study was on the contrary to the result of the research conducted by Irawati (2012) which stated that profit growth affected significant negative on the quality of profits. Profit growth did not affect to the profits quality was possible because of data of banking profit growth in this study mostly from year to year was always decreasing. Even, in 2014 many banking companies that experienced minus profit growth. In other words, the company's net profit experienced decrease. So that, it was expected from these data that led profit growth did not affect on the quality of profits. 
Liquidity is a financial ratio that showed company's ability to meet all short-term liabilities. Liquidity that was measured using current ratio proxy described the ratio of total current assets to the amount of current liabilities. Liquid condition was a condition in which the company was able to meet short-term liabilities. From analysis results about the effect of liquidity on the quality of profits, could be seen in table 3 that showed significant value $>0.05$ that was 0.814 , which meant $\mathrm{H} 4$ in this study was rejected. It could be interpreted that liquidity did not affect on the profit quality of a company. This research was in accordance with research conducted by Yushita \& Triatmoko (2013) which stated that liquidity did not affect the quality of profits. However, this result of this study was on the contrary to study conducted by Wulansari (2013) which stated that firm size affected significant positive on the quality of profit. Liquidity did not affect on the quality of profits was possible because the liquid company was not necessarily the solvable company. It meant that the company was in a condition that no longer has good financial balance, because the company had the ability to pay their short-term debt well but it was not able to pay off all the debts well. In addition, companies with a high liquidity value feared it was not optimal in using cash that will result in a decrease of profitability.

Firm size was a scale in which a company can be classified into small or big companies according to a variety of ways, including total assets, log size, sales and stock market value. Firm size in this study was measured by log of total asset value owned by each company. From analysis result about the effect of firm size on the quality of profits, could be seen in table 3 that showed significance value $<0.05$ that was 0.00 which meant $\mathrm{H} 5$ in this study was accepted. It could be interpreted that firm size affected on the profit quality of a company's. The result of this study was in accordance with research conducted by Romasari (2013) which stated firm size affected the quality of profits. Companies that have gone public typically tend to have a large size of the company. Companies that have large total assets could generate greater profits than companies with little or low total assets. Companies with a relatively large performance will be viewed by the public so that the company will report its financial condition to be more careful, to more show informativeness of the information contained in it and more transparent so that the company would be less in earning management. The magnitude of the size of a company would be supervised by concerned parties especially by investors, usually they would be more interested in a large company, because it would enable the company to generate greater profits than the smaller companies.

\section{CONCLUSION}

The results show that the variables of institutional ownership and firm size affect the quality of profits. Whereas, the variables of managerial ownership, profit growth and liquidity do not affect the quality of profits. Suggestion for further research is in order to add the period of observation year or by adding an intervening variable so that the results obtained could be better. 


\section{REFERENCES}

Diantimala, Y. (2008). Pengaruh Akuntansi Konservatif, Ukuran Perusahaan, dan Default Risk Terhadap Koefisien Respon laba (ERC). Jurnal Telaah Dan Riset Akuntansi, 1(1), 102-122.

Dira, K. P., \& Astika, I. B. P. (2014). Pengaruh Struktur Modal, Likuiditas, Pertumbuhan Laba, dan Ukuran Perusahaan pada Kualitas Laba. E-Jurnal Akuntansi, 7(1), 64-78.

Hesti, D. A., \& Syaichu, M. (2010). Analisis Pengaruh Ukuran Perusahaan, Kecukupan Modal, Kualitas Aktiva Produktif (KAP), dan Likuiditas Terhadap Kinerja Keuangan (Studi Pada Bank Umum Syariah di Indonesia Periode 2005-2009). UNIVERSITAS DIPONEGORO.

Irawati, D. E. (2012). Pengaruh struktur modal, pertumbuhan laba, ukuran perusahaan dan likuiditas terhadap kualitas laba. Accounting Analysis Journal, 1(2).

Mojtahedi, P. (2013). The Impact of Intellectual Capital on Earning Quality: Evidence from Malaysian Firms. Australian Journal of Basic and Applied Sciences, 7(2), 535-540.

Moradi, M. A., \& Nezami, A. (2011). Influence of ownership structure on earning quality in the listed firms of Tehran Stock Exchange. International Journal of Business Administration, 2(4), 146-154.

Romasari, S. (2013). Pengaruh Persistensi Laba, Struktur Modal, Ukuran Perusahaan dan Alokasi Pajak Antar Periode Terhadap Kualitas Laba (Studi Empiris pada Perusahaan Manufaktur yang Terdaftar di BEI). Jurnal Akuntansi, $1(2)$.

Schipper, K., \& Vincent, L. (2003). Earnings quality. Accounting Horizons, 17, 97-110.

Siallagan, H., \& Machfoedz, M. (2006). Mekanisme corporate governance, kualitas laba dan nilai perusahaan. Simposium Nasional Akuntansi IX. Padang, 23-26.

Veronica, Sylvia, and Sidharta Utama. 2005. Pengaruh Struktur Kepemilikan, Ukuran Perusahaan, dan Praktek Corporate Governance terhadap Pengelolaan Laba (Earnings Management). Artikel Simposium Nasional Akuntansi (SNA) VIII, IAI, Solo.

Wulansari, Y. (2013). Pengaruh Investment Opportunity Set, Likuiditas Dan Leverage Terhadap Kualitas Laba Pada Perusahaan Manufaktur Yang Terdaftar Di BEI. Jurnal Akuntansi, 1(2).

Yushita, A. N., \& Triatmoko, H. (2013). Pengaruh Mekanisme Corporate Governance, Kualitas Auditor Eksternal, Dan Likuiditas Terhadap Kualitas Laba. Jurnal Economia, 9(2), 141-155. 